UDK 811.134.2'372:159.97

165.194:81

616.89:81

Izvorni znanstveni članak

Prihvaćeno za tisak: 11. svibnja 2020.

https://doi.org/10.22210/suvlin.2020.089.03

\author{
Vanja Kljajevic ${ }^{1}$, Johanne Hatteland Somme ${ }^{2}$, Rosa Prieto Tedejo ${ }^{2}$, Garazi Laseca ${ }^{3}$ \\ ${ }^{1}$ Ikerbasque, Basque Foundation for Science, Bilbao, Spain, ${ }^{2}$ University Hospital Alava, Vitoria, \\ Spain, ${ }^{3}$ Complutense University of Madrid, Madrid, Spain \\ vanja.kljajevic@gmail.com
}

\title{
Comprehension of psychological predicates in Alzheimer's disease
}

\begin{abstract}
Patients with Alzheimer's disease (AD) show a deficit in processing sentences with psychological verbs. Evidence from English suggests that their comprehension of object Experiencers is more impaired relative to subject Experiencers. Since Spanish is structurally different from English, in the present study we wanted to determine whether Spanish-speaking AD patients would show a different comprehension pattern. We tested comprehension of semantically irreversible sentences involving psych verbs with subject Experiencers, and accusative- and dative-marked object Experiencers in 10 native speakers of Spanish diagnosed with mild to moderate AD. We also tested their comprehension of semantically reversible sentences involving dative object Experiencers in two word orders (SVO, OVS). A paired-samples t-test revealed no statistically significant differences in their comprehension of subject vs. object Experiencers, or accusative vs. dative object Experiencers in semantically irreversible sentences, with one-sample $t$-test indicating comprehension above chance. However, their overall comprehension of psych verbs in semantically reversible sentences was poor, regardless of word order, and it was significantly worse than their comprehension of sentences with action verbs in the same word orders. Thus, our data indicate that the deficit in comprehension of psych verbs found in Spanish speakers with mild to moderate AD dementia differs from the pattern found in English, and that the deficit in AD patients' comprehension of psych verbs is more heterogeneous than previously thought.
\end{abstract}

\section{Introduction}

Alzheimer's disease (AD) is a progressive neurological disease that affects multiple cognitive functions, such as memory, executive function, language, visuospatial abilities, decision making, reasoning, judgment, affective processing, and behavior (Dubois et al. 2010). The "cortical signature" of AD is regional brain atrophy, i.e. reduction in volume and cortical thickness of grey matter areas, which begins in medial temporal lobe and then spreads to lateral temporal and other brain regions, 
affecting frontal lobe structures at a later stage (Dickerson et al. 2009; Kljajevic et al. 2014). Medial temporal structures support emotion inhibition and lateral temporal structures support so-called socioemotional processes (e.g., face, prosody, intention and trustworthiness evaluations); thus, atrophic changes of these brain areas have impact on affective processing in AD patients (Sturm et al. 2013). Importantly, degeneration of amygdala, which is a key structure for generation of emotions, begins early in the disease development, leading to early deterioration of emotional processing in $\mathrm{AD}$.

Emotions are brief psychological states, such as delight, anger, or fright, which some researchers distinguish from more stable emotional tendencies, or dispositions, such as love, hatred, or liking (Ekman 1999). Emotions appear to support formation and retrieval of representations of past events from long-term memory (Dere et al. 2010). They affect word retrieval for both concrete and abstract words (Giffard et al. 2015). Impaired processing of emotions in AD has been associated with impairments of emotional memory (Parra et al. 2013), emotional prosody (Taler et al. 2008), and processing of facial expressions.

Not only that $\mathrm{AD}$ patients have disturbances in the processing of emotions and emotion-related information, but verbs denoting psychological states (e.g. fear denotes the state of fright) are also impaired in AD. Verbs such as fear, love, amuse, belong to the class of verbs known as "psychological verbs" (henceforth psych verbs). Growing evidence suggests that $\mathrm{AD}$ patients have a general difficulty with verb processing (Robinson et al. 1996; White-Devine et al. 1996; Grossman et al. 2007), but it is currently not clear whether this verb deficit is due to grammatical or semantic reasons (Kim \& Thompson 2004). Recent research involving psych verbs suggests that an important aspect of semantic processing may be causing verb processing deficit in $\mathrm{AD}$ patients. This aspect is not related to the semantic content of verbs, but rather to the processing of thematic roles (Manouilidou et al. 2009). Thematic roles carry information on semantic relations between elements in a given sentence, such as "who did what to whom" or in the case of psych verbs "who feels what for whom". More specifically, studying comprehension of semantically irreversible sentences with psych verbs in 10 mild to moderate AD patients, Manouilidou et al. (2009) found that the patients performed considerably worse relative to cognitively healthy elderly participants. Furthermore, AD patients' comprehension of object Experiencers was considerably worse than their comprehension of subject Experiencers. That is, $\mathrm{AD}$ patients comprehended better sentences such as The boy fears the thunder, in which the subject of sentence the boy is associated with the thematic role of Experiencer, than sentences such as The thunder frightens the boy, where the boy is still Experiencer, but now in the object position. Further evidence from English suggests that patients with other neurological conditions, such as post-stroke aphasia, also show worse performance on verbs taking object Experiencers relative to verbs taking subject Experiencers (Piñango 2000; Thompson and Lee 2009). Increased processing costs associated with object Experiencers relative 
to subject Experiencers, indicated by longer reading times, lower accuracy rates, and/or different brain activation patterns, were found in healthy young speakers of English (Brennan and Pylkkänen 2010). Evidence on comprehension of object Experiencers in healthy young speakers of Spanish obtained in a reading task indicate a better comprehension of sentences appearing in OVS than in SVO order, and the opposite pattern, better comprehension of sentences appearing in SVO than in OVS order, when sentences in the same frame contained activity verbs (Gattei et al. 2015). This pattern was observed in semantically reversible sentences, suggesting facilitating effects of morphosyntactic cues (section 1.1).

It has been claimed on syntactic and semantic grounds that object Experiencers are more complex than subject Experiencers (e.g. Pesetsky 1995; Fábregas \& Marín 2016), implying that they impose a higher processing load, which is consistent with the comprehension pattern observed in English AD patients. However, this pattern may not hold for $\mathrm{AD}$ patients who speak languages structurally different from English. This question has not been sufficiently explored to date. Spanish is an interesting language in this regard, because its flexible word order allows raising interesting questions related to Experiencers (section 1.1). Thus, one goal of the present study was to determine the ability of Spanish-speaking AD patients to comprehend psych verbs (e.g., fear, frighten) and map them to a function in sentence (subject, direct object, indirect object).

Linguistically, psych verbs are intriguing: crosslinguistic evidence suggests that the grammar recognizes the "cognitive primacy" of Experiencers by allowing them a special status (Wierzbicka 1981; Landau 2010). Psych effects, i.e. specific syntactic properties associated with Experiencers, are found across languages (Landau 2010), which differ with regard to whether their psych verbs are mostly object Experiencers (frighten-type), as found in English, or mostly subject Experiencers (fear-type), as found in Japanese (Hartshorne et al. 2016). It has been pointed out that because they are nonagentive, they allow for testing of hypotheses on mappings between semantic arguments and syntactic positions other than Subject-Agent (Piñango 2000). While this observation holds for stative psych verbs, it is important to recognise that there is a class of psych verbs that are ambiguous between psych and agentive readings (Landau 2010). Spanish resolves this ambiguity by case marking and the clitic doubling the object.

\subsection{Experiencers in Spanish}

Although its canonical word order is subject-verb-object (SVO), the Spanish language has a relatively free word order, so that sentence in (1) can have ten other word orders and still remain grammatical and acceptable (De Bruyne 1995).

(1) El cartero trajo una carta para mi.

The postman brought a letter forme. 
The different word orders correspond to subtle differences in meaning, related to which element of the sentence is stressed. In Spanish declarative sentences in which a subject or verb appears in the initial position, it is the final element that carries stress. However, if an object or prepositional phrase is in the initial position, the first element is stressed.

Semantically reversible sentences in (2) and (3) have the same meaning, even though they differ in the order of arguments:
(2) El chico
le
the boy ${ }_{\text {NOM }}$
clitic $_{\text {DAT }}$
grita a la chica.
(3) Ala chica
le
yells to the girl ${ }_{\mathrm{DAT}}$
to the girl
clitic $_{\text {DAT }}$
The boy yells at the girl.
grita el chico.
yells the boy ${ }_{\mathrm{NOM}}$

Namely, in (2), the subject precedes the object, whereas in (3) the object appears in the sentence initial position, preceding the subject. The information on "who is doing what to whom" in this case is conveyed by the particle $a$, which typically marks animate objects, case marking, i.e. the dative pronoun le, and the clitic doubling the object, i.e. the coreference between le and la chica. Thus, the order of thematic roles corresponds to the canonical hierarchy of thematic roles1 (Agent, Patient) in (2) but not in (3), where it is reversed, i.e. the Patient precedes the Agent.

Psych verbs require different thematic hierarchies and impose a different type of mapping of thematic roles on to syntactic functions, allowing a linking between the thematic role of Experiencer and both the syntactic function of subject, as in (4), and object, as in (5) and (6).

(4) Pepeama a María.--Subject Experiencer

Pepeloves ACC María.

Pepeloves María. $\begin{array}{llll}\text { (5) El fuego asusta } & \text { a } & \text { Pepe.--Object Experiencer } \\ \text { the fire frightens } & \text { ACC } & \text { Pepe }\end{array}$

The fire frightens Pepe.
(6) El teatro le gusta a Pepe.--Object Experiencer
The theater $\mathrm{CL}_{\mathrm{DAT}}$ pleases DAT Pepe
Pepe likes the theater.

1 While there are different thematic hierarchies (e.g. those proposed by Fillmore, Jackendoff, Baker, Grimshaw, Van Valin among others), which may differ in the order of specific roles, they all postulate that in a canonical thematic roles hierarchy Agent takes the most prominent position in the sentence, i.e. the subject position. 
The tripartite classification of psych verbs (class I: nominative Experiencer, accusative Theme; class II: nominative Theme, accusative Experiencer; class III: nominative Theme, dative Experiencer), which was originally proposed by Belletti and Rizzi (1988), together with the peculiar nature of dative Experiencer verbs, has motivated theoretical linguistic research, mostly within the Relational Grammar, Government and Binding Theory, and Minimalism. Franco (1990) pointed out that the distinction between class II and class III psych verbs in Spanish is sometimes blurred, with some dialects marking all object Experiencers as dative while in other dialects homophonous forms of Experiencers alternate between accusative and dative markings of the arguments. The clitic doubling the object resolves the case ambiguity. Crucially, the psych verbs that alternate between accusative and dative markings of the arguments are ambiguous between agentive and psych readings, and when used agentively, as in María lo $_{\mathrm{AcC}}$ enojó a Pepe (María $\mathrm{Cl}_{\mathrm{ACC}}$ anger to Pepe, "Maria angered Pepe"), psych effects disappear and they pattern with normal transitive verbs (Landau 2010). However, even though they may appear with Agent subjects, these accusatives "still preserve their Experiencer status since they never take part in the syntactic processes in which accusative Patients do" (Franco 1999: 133).

Despite syntactic differences, sentences in (4)-(6) do not differ in terms of thematic relations they express, given that each contains an Experiencer that is emotionally reacting to a Theme. The Theme is realized as the subject in (5) and (6) and as the object in (4), whereas the Experiencer is realized as the subject in (4), as the direct object in (5) and as the indirect object in (6). What is puzzling here is the flexibility of role-function mapping, i.e. the fact that three syntactically different constructions convey apparently equivalent thematic relations. This makes psych verbs an intriguing topic to study in neurological patients with verb deficits, allowing for investigation of more fine-grained questions related to the nature of these deficits.

In the present study, we investigated the ability of mild-to-moderate AD patients who were native speakers of Spanish to comprehend sentences with psych verbs. Since Spanish has a relatively free word order, clitic doubling, and expresses the object Experiencer role via accusative and dative cases, both marked by the particle $a$ for animate objects, we hypothesized that Spanish AD patients would show a pattern of comprehension of psych verbs different from the one found in English-speaking AD patients (Manouilidou et al. 2009). Furthermore, since OVS is a canonical order for dative object Experiencers (Jiménez-Fernández \& Rozwadowska 2016), we wanted to establish if a word order (SVO vs. OVS) would affect patients' comprehension of these Experiencers. Finally, given that memory deficits are a hallmark of cognitive deterioration in $\mathrm{AD}$, we wanted to determine whether incidental memory for psych verbs, action verbs, and nouns would be spared in $\mathrm{AD}$ patients and if not, whether it would be equally or differentially affected. 


\section{Methods}

\subsection{Participants}

Ten $\mathrm{AD}$ patients (five males and five females), who were recruited through the Neurology Department of the University Hospital of Alava in Vitoria, participated in the study. At the time of testing, there were only $15 \mathrm{AD}$ patients who met our study's inclusion and exclusion criteria (specified below) at the University Hospital's memory clinic database and only 10 of them were available to take part in the study. Adding to the difficulties with patients' recruitment for the present study was also the problem of finding monolingual speakers in a bilingual (SpanishBasque) community. In addition, two cognitively normal elderly participants, recruited from the community, completed the protocol to ensure that the tests were appropriate to administer, i.e. that neurologically intact older individuals could complete them.

As specified by study's inclusion criteria, all participants were native speakers of Spanish, monolingual, and right-handed. Furthermore, they were all diagnosed with $\mathrm{AD}$ according to the National Institute of Neurological and Communicative Disorders and Stroke - Alzheimer's Disease and Related Disorders Association (NINCDS-ADRDA) Alzheimer's criteria (McKhann et al. 1984), and had mild to moderate dementia, having a Mini Mental State Exam (MMSE) (Folstein et al. 1975) score of 15 or better. Exclusion criteria were: stroke, neurological conditions (other than $\mathrm{AD}$ in $\mathrm{AD}$ patients), psychiatric conditions such as schizophrenia or severe depression, and use of medications that could severely affect performance on cognitive tests. Since it is not possible to fully control for potential effects of medications on cognitive performance in $\mathrm{AD}$ patients, to reduce such effects, we did not include subjects receiving psychotropic medications at doses known to affect cognition. However, AD patients were allowed to continue using their specific medication for $\mathrm{AD}$, i.e. acetylcholinesterase inhibitor (AChEI) and memantine.

All participants completed Montreal Cognitive Assessment (MoCA) (Nasreddine et al. 2005), which is more sensitive to cognitive deterioration than MMSE. All participants had normal hearing and normal or corrected to normal visual acuity. Participants' characteristics are summarized in Table 1.

\begin{tabular}{|l|l|l|l|l|}
\hline Study-ID & Age & Gender & Edu & MoCA \\
\hline AD01 & 55 & m & 12 & 25 \\
\hline AD02 & 75 & m & 14 & 8 \\
\hline AD03 & 64 & m & 10 & 10 \\
\hline AD04 & 82 & f & 8 & 7 \\
\hline AD05 & 70 & f & 8 & 14 \\
\hline AD06 & 54 & f & 17 & 6 \\
\hline
\end{tabular}




\begin{tabular}{|l|l|l|l|l|}
\hline AD07 & 64 & $\mathrm{~m}$ & 10 & 14 \\
\hline AD08 & 75 & $\mathrm{~m}$ & 8 & 8 \\
\hline AD09 & 80 & $\mathrm{f}$ & 8 & 11 \\
\hline AD10 & 87 & $\mathrm{f}$ & 8 & 5 \\
\hline HC01 & 67 & $\mathrm{~m}$ & 10 & 26 \\
\hline HC02 & 69 & $\mathrm{~m}$ & 8 & 24 \\
\hline
\end{tabular}

Table 1: Participants' characteristics.

AD participants' age ranged from 54 to 87 (mean, SD: $70.6 \pm 11.3$ ). Their formal education ranged from 8 to 17 years $(10.3 \pm 3.1)$ and MoCA scores from 5 to 25 (10.8 \pm 5.9$)$. The MoCA scores indicate that three patients had mild dementia (scores 11-17), five patients had moderate dementia (scores 6-10), with one patient (AD10) falling into severe dementia $(<6)$, and one patient (AD01) minimally deflecting from normal cognitive status $(\geq 26)$. The patient with severe dementia completed all tests, but her scores were not entered into analysis. The age $(68 \pm 1.4)$ and years of formal education $(9 \pm 1.4)$ in two healthy controls were comparable to those of patients, but they achieved considerably higher scores on MoCA $(25 \pm 1.4)$. They completed with little difficulty all the tasks and their data will not be further discussed.

\subsection{Experiments}

To assess $\mathrm{AD}$ patients' comprehension of psych verbs, we designed two experiments and a post-experimental test, addressing the following research questions:

(i) Are subject Experiencers easier to comprehend than object Experiencers? (Experiment 1)

(ii) Are accusative-marked object Experiencers easier to comprehend than dative-marked object Experiencers? (Experiment 1)

(iii) Given the same sentence frame, are psych verbs more difficult to comprehend than action verbs? (Experiment 2)

(iv) Are dative object Experiencers easier to comprehend in sentences with OVS order than in sentences with SVO order? (Experiment 2)

(v) Is incidental memory for psych verbs affected in $\mathrm{AD}$ patients relative to action verbs and nouns? (Post-experimental test)

Experiment 1 was an acceptability judgment test, which assessed patients' ability to differentiate between semantically plausible (i.e. acceptable) and semantically implausible (i.e. unacceptable) sentences with psych verbs taking subject Experiencers, accusative object Experiencers and dative object Experiencers. While all the sentences were grammatically correct, semantic plausibility was manipulated in a half of the sentences by reversing the thematic roles in semantically plausible 
sentences, and since there was only one argument of the verb that was animate, the reversal of thematic roles resulted in semantically implausible sentences. The sentences systematically varied between subject Experiencers and object Experiencers marked by accusative and dative. Thus, the experiment consisted of 6 conditions (three types of Experiencers $x$ two variants of plausibility), each containing 10 sentences. Examples of sentences from all conditions are given in Table 2.

Experiment 2 tested $\mathrm{AD}$ patients' comprehension of semantically reversible sentences with psych verbs taking dative object Experiencers and actions verbs in two word orders: SVO and OVS. Thus, there were four types of sentences, containing: (a) psych verbs in SVO order $(\mathrm{n}=10),(\mathrm{b})$ psych verbs in OVS order $(\mathrm{n}=10),(\mathrm{c})$ action verbs in SVO order $(n=10)$ and $(c)$ action verbs in OVS order $(n=10)$. This experiment was a partial replication and adaptation of Experiment 1 from Gattei et al.'s study (2015), with the stimuli created as 10 sets of four types of sentences. Crucially, four types of sentences were created within the same sentence frame for each of 10 sets (Table 2, examples a-d). Each target sentence was followed by a comprehension question related to the content of the target sentence. For half of the sentences in each condition the correct answer was "Yes" and for the other half the correct answer was "No". There was an equal number of masculine and feminine nouns in the target positions across all conditions in both experiments ${ }^{2}$.

\begin{tabular}{|c|c|}
\hline Condition & Example \\
\hline SP-SE & La niña teme el vuelo. The girl fears the flight. \\
\hline SI-SE & El vuelo teme a la niña. The flight fears the girl. \\
\hline $\mathrm{SP}-\mathrm{OE} \mathrm{ACC}_{\mathrm{A}}$ & El juguete fascina al niño. The toy fascinates the boy. \\
\hline $\mathrm{SI}-\mathrm{OE} \mathrm{ACC}_{\mathrm{A}}$ & El niño fascina al juguete. The boy fascinates the toy. \\
\hline $\mathrm{SP}-\mathrm{OE} \mathrm{E}_{\mathrm{DAT}}$ & Al cocinero le apetece la cerveza. The cook wants a beer. \\
\hline $\mathrm{SI}-\mathrm{OE}_{\mathrm{DAT}}$ & A la cerveza le apetece el cocinero. The beer wants the cook. \\
\hline a. PsychVerb-SVO & $\begin{array}{l}\text { La abuela le apena a la mujer de vestido rojo. } \\
{\text { The granny } \mathrm{CL}_{\mathrm{DAT}} \text { feels sorry to the woman }}_{\text {DAT }} \text { of dress red. } \\
\text { The woman in red dress feels sorry for the granny. } \\
\mathrm{Q}: \text { ¿Es la abuela por quién alguien se siente triste? } \\
\text { Is the granny for whom someone feels sorry? }\end{array}$ \\
\hline b. PsychVerb-OVS & $\begin{array}{l}\text { A la mujer le apena la abuela de vestido rojo. } \\
\text { To the woman }{ }_{\text {DAT }} C L_{\text {DAf }} \text { feels sorry the granny of dress red. } \\
\text { The woman feels sorry for the granny in red dress. } \\
\text { Q: ¿Es la abuela por quién alguien se siente triste? } \\
\text { Is the granny for whom someone feels sorry? }\end{array}$ \\
\hline
\end{tabular}

2 Note that some examples in Table 2 contain al: it is a contraction driven by phonological reasons of the particle $a$ and the definite article for masculine singular el (e.g. al cocinero, "cook"). This does not apply to feminine nouns (e.g. a la cerveza, "beer"). 


\begin{tabular}{|c|c|}
\hline c. ActionVerb-SVO & $\begin{array}{l}\text { La abuela le ruega a la mujer de vestido rojo. } \\
\text { The granny } \mathrm{CL}_{\mathrm{DAT}} \text { begs to the woman } \\
\text { The granny of dress red. } \\
\mathrm{Q} \text { : ¿Es la abuela quién suplica a alguien? } \\
\text { Is the granny who begs someone? }\end{array}$ \\
\hline d.ActionVerb-OVS & $\begin{array}{l}\text { A la mujer le ruega la abuela de vestido rojo. } \\
\text { To the woman }{ }_{\text {DAT }} \text { CL } \text { DAT begs the granny of dress red. } \\
\text { The granny in red dress begs the woman. } \\
\text { Q: ¿Es la abuela quién suplica a alguien? } \\
\text { Is the granny who begs someone? }\end{array}$ \\
\hline
\end{tabular}

Table 2: Examples of sentences in all conditions in two experiments.

SP-SE = semantically plausible Subject-Experiencer; SI-SE = semantically implausible Subject-Experiencer; $\mathrm{SP}-\mathrm{OE}_{\mathrm{ACC}}=$ semantically plausible Object-Experiencer $_{\mathrm{ACC}} ; \mathrm{SI}-\mathrm{OE}_{\mathrm{ACC}}=$ semantically implausible Object-Experiencer ${ }_{\mathrm{ACC}} ; \mathrm{SP}-\mathrm{OE}_{\mathrm{DAT}}=$

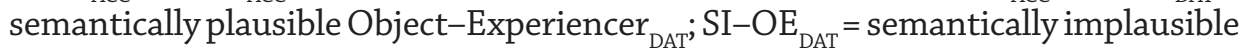
Object-Experiencer $_{\text {DAT. }} \mathrm{CL}=$ clitic.

Finally, the test of incidental memory was administered after the participants completed Experiment 2. It tested incidental memory for psych verbs relative to action verbs, on the one hand, and incidental memory for verbs relative to nouns, on the other. The test consisted of 20 psych verbs, 20 action verbs, and 20 nouns (10 masculine, 10 feminine). Only half of the 20 stimuli in each class were selected from those used in Experiments 1 and 2; the remaining stimuli in each class were novel words belonging to that class. The task was to decide for each stimulus whether it already appeared in the experiments or not.

Thus, there was a total of 100 sentences, with 60 sentences in Experiment 1 and 40 sentences in Experiment 2, and a total of 60 words in the test of incidental memory. All the stimuli within a respective test were randomized in Excel and then reordered in such a way that the same condition did not appear more than twice in a row.

\subsection{Procedures}

All patients underwent a neurological exam at the University Hospital Alava in Vitoria. During the exam the neurologists on the team (J.H.S. and R.P.T.) determined patients' eligibility for the study, based on the inclusion and exclusion criteria (section 2.1). Each participant signed informed consent prior to the study, which was conducted in accordance with the Helsinki guidelines for research studies involving human subjects.

The experimenter first described the whole testing session, except for the test of incidental memory, which was introduced later. Participants then completed 
MoCA. After the experimenter gave thorough instructions and after participants completed six practice trials, Experiment 1 was administered. There were 6 practice trials before each task to make sure that the participants understood the task at hand. During the practice trials, the experimenter provided a feedback, but no feedback was given during actual testing. There was a short break after Experiment 1, during which participants were offered water and asked how they felt and whether they were tired. Then Experiment 2 was administered, followed by a short break, which was followed by the test of incidental memory. The stimuli were presented to all participants in the same order. The time to respond was not limited. The tests were administered to all patients by the same research assistant (G.M.), who is a native speaker of Spanish. Using the normal reading rate, she read the stimuli and marked patients' answers in a separate form for each experiment that was prepared for each individual. The responses were scored for accuracy later, with each correct response scoring one point.

The patients were tested individually, in a quiet room at the University Hospital in Vitoria. The healthy control speakers (HCs) were tested individually at their homes. The neurological exam and patients' testing for the present study were completed in two separate sessions on a different day. The neurological exam took about one hour per patient, and patients' testing for the present study lasted between one hour and one hour and 15 minutes. One patient (AD06), who had to leave early because of the care giver's schedule conflict, completed only MoCA and Experiment 1 and was unable to continue testing at a later date. HCs completed the tests in one session, which lasted about 30 minutes.

\subsection{Statistical analysis}

One-sample $t$-test was conducted to determine if the mean score in the AD group would differ from a hypothetical dataset representing chance. The chance level was calculated for each condition using the probability of 0.5 in obtaining a certain score. We then conducted paired-samples $t$-tests to establish whether the differences in scores on pairs of conditions within each test were statistically significant. Pearson correlation test was conducted to establish possible associations between the patients' scores in each condition and their MoCA scores, on the one hand, and their scores on incidental memory test, on the other. An alpha level of $p<$ .05 was set for all analyses and the results were corrected for multiple comparisons using a Bonferroni correction (i.e. the significance threshold .05 was divided by the number of comparisons in each test), thus ensuring that the familywise error rate is controlled. Since each test consists of a different number of conditions, different adjusted significance thresholds were used to correct the results. All tests were two-tailed. For all analyses we used SPSS 22. 


\section{Results}

One sample $t$-test revealed that $\mathrm{AD}$ patients' comprehension of semantically irreversible plausible sentences with psych verbs was above chance, including subject Experiencers $(t(8)=8.98, p<.001)$, accusative object Experiencers $(t(8)=12.1$, $p<.001)$ and dative object Experiencers $(t(8)=9.43, p<.001)$, with the results surviving a Bonferroni correction at an adjusted significance threshold of .008. However, their comprehension of semantically implausible sentences was not significantly different from chance, except for accusative object Experiencers $(t(8)=2.64$, $p=.03$ ), but this result did not survive the correction.

A paired-samples $t$-test revealed statistically significant differences between $\mathrm{AD}$ patients' comprehension of semantically plausible and semantically implausible subject Experiencers $(t(8)=2.29, p=.05)$, between semantically plausible and semantically implausible accusative object Experiencers $(t(8)=2.5, p=.037)$, and between semantically plausible and semantically implausible dative object Experiencers $(t(8)=3.65, p=.006)$, but only the last result survived the correction. There were no statistically significant differences between subject and object Experiencers, or between the two types of object Experiencers either within semantically plausible or implausible sentences.

As for semantically reversible sentences, one-sample $t$-test showed that $\mathrm{AD}$ patients' comprehension of sentences with psych verbs was not significantly different from chance, regardless of whether the sentences involved SVO order $(t(7)=$ $.16, p=.87$, n.s.) or OVS order $(t(7)=1.37, p=.21$, n.s.), whereas their comprehension of sentences with action verbs was preserved both in SVO order $(t(7)=4.77, p$ $=.002$ ) and in OVS order $(t(7)=4.25, p=.004)$, both results surviving a correction for multiple comparisons.

A direct comparison of $\mathrm{AD}$ patients' comprehension of sentences with psych verbs vs. action verbs showed a statistically significant difference $(t(7)=3.309, p$ $=.013$ ), which survived the correction (for $p<.016$ ), but there were no statistically significant differences in their comprehension of sentences with psych verbs in SVO vs. OVS order, nor in their comprehension of sentences with action verbs in SVO vs. OVS order.

As for $\mathrm{AD}$ patients' recollection of incidentally encoded psych verbs, although it was above chance $(t(7)=4.33, p=.003)$, it was not significantly better than their recollection of action verbs after the correction $(t(8)=2.81, p=.026>.016)$.

Finally, the results of Pearson correlation test indicate a lack of significant associations between patients' MoCA scores and their scores on experimental tests, suggesting that $\mathrm{MoCA}$ is not sensitive enough to register verb deficits in $\mathrm{AD}$ dementia, as discussed in section 4 .

Thus, the main findings of the study are that Spanish speaking AD patients with mild to moderate dementia have preserved comprehension of irreversible 
sentences with psych verbs, regardless of the type of Experiencer (subject, object) or case marking of object Experiencers (accusative, dative), as long as the sentences are plausible; however, they had difficulty rejecting semantically implausible sentences with the same psych verbs as meaningless. In semantically reversible sentences, patients' comprehension of sentences with dative object Experiencers was deficient regardless of the type of word order (unmarked OVS, marked SVO), although their comprehension of the sentences created in the same frame but using action verbs instead of psych verbs was spared regardless of the type of word order (unmarked SVO, marked OVS).

Patients' performance on all conditions is summarized in Figure 1.

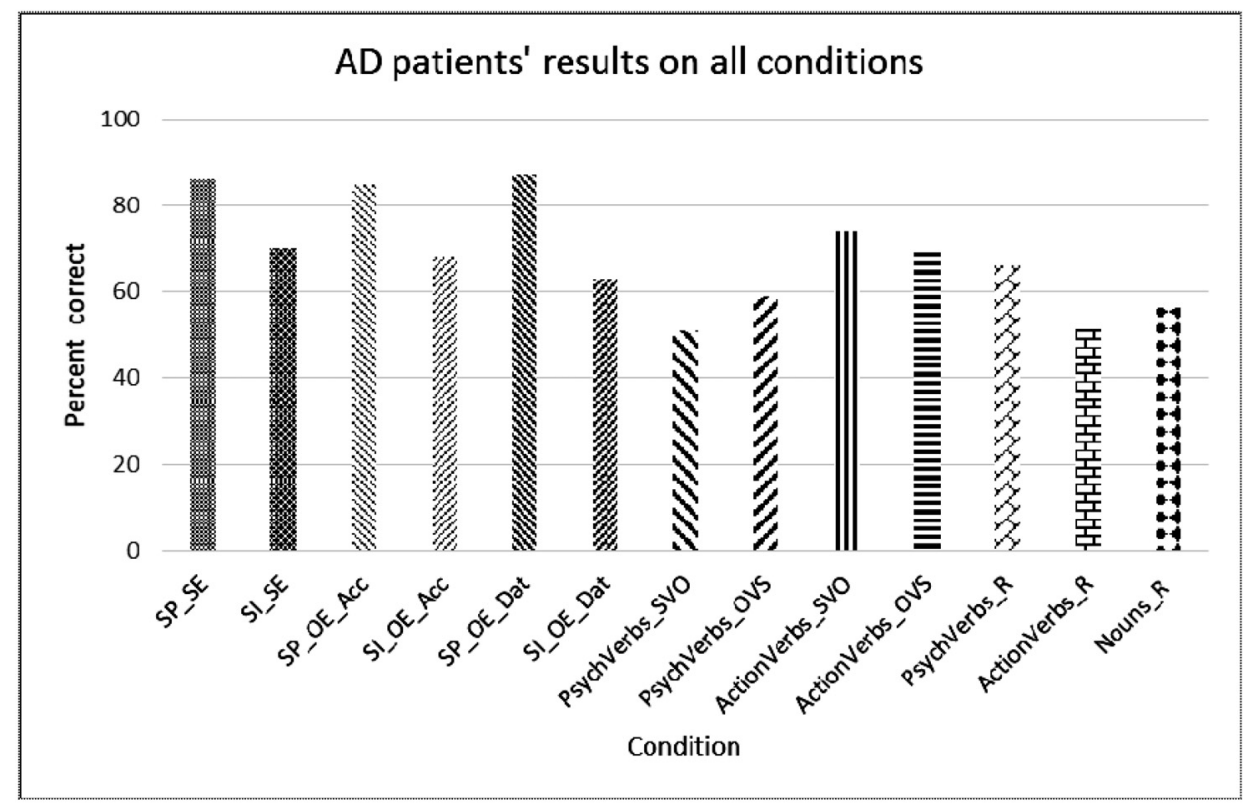

Fig. 1: Mean percentage correct comprehension and recall (R) across all conditions in $\mathrm{AD}$ patients.

\section{Discussion}

The present data suggest that Spanish-speaking AD patients have spared comprehension of semantically irreversible sentences with psych verbs regardless of the type of Experiencer (subject Experiencer, accusative object Experiencer, dative object Experiencer), as long as sentences are semantically plausible. It has been pointed out that semantic plausibility depends on real-world knowledge, rather than linguistic knowledge about semantic representation. Since declarative memory deteriorates early in $\mathrm{AD}$, it is likely that the patients' poor performance on se- 
mantically implausible sentences in the present study reflects the deterioration of semantic memory, rather than specifically a language deficit. Put differently, it is likely that they found the semantically implausible sentences generally too confusing, since such sentences defy common sense by assigning animate features to inanimate entities and as such do not come up in normal everyday communication. Considering previous findings from English, which suggest overall poor comprehension of semantically irreversible sentences with psych verbs, with better comprehension of subject than object Experiencers (Manouilidou et al. 2009), our findings indicate a different comprehension pattern in Spanish speaking AD patients.

However, our data align with the notion that when object Experiencers, in this case dative marked, are encountered in semantically reversible sentences, they cause comprehension difficulties to AD patients. Linguistically, such object Experiencers are much more interesting, in particular in light of the fact that we studied dative object Experiencers in two different orders, with <Experiencer, Theme> being a canonical thematic order in this type of sentences in Spanish (JiménezFernández \& Rozwadowska 2016). The impaired comprehension of sentences with dative object Experiencers in our AD patients is surprising, considering the multiple cues to meaning, in particular in the OVS order where the preposition $a$, indicating an animate object, appears in the sentence initial position. Evidence involving neurologically intact population, including child language, as well as post-stroke aphasic patients (Kail \& Charvillat 1988; Ostrosky-Solis et al. 1999; Kljajevic et al. 2019) converges in suggesting that this specific cue to animate objects in Spanish typically facilitates comprehension of the Patient role in agentive context. In the present study, $\mathrm{AD}$ patients comprehended above chance sentences with action verbs involving dative objects in both word orders, but they failed to comprehend sentences with psych verbs taking dative Experiencers. Is there something peculiar to dative Experiencers that prohibits facilitating effects of cues to meaning?

The status of Spanish dative Experiencers is a matter of debate, revolving around the question whether they are indeed objects or perhaps subjects, given their co-occurrence with adverbs such as solamente "only" which are compatible with subjects but not with clitic left dislocated topics (Massulo 1992), or given that they appear preverbally in "out-of-the-blue" sentences (Fernández-Soriano 1999). Others, however, hold that dative Experiencers are preverbal because they move to Spec-TP and not because they are subjects (Jiménez-Fernández \& Rozwadowska 2016), suggesting that the concept of subject needs to be revised for Spanish and subscribing to a deconstructed concept of subjecthood, whose specific properties may be distributed over structural positions, case, agreement, topicality and so on, and therefore may dissociate (Landau 2010). We leave the complex issues raised by this debate for future research. 
Taken together, the results of the present study indicate that $\mathrm{AD}$ patients' deficit in the comprehension of psych verbs is not as homogenous as previously thought, as semantically irreversible sentences did not pose a difficulty regardless of the type of Experiencer (subject Experiencer, accusative object Experiencer, dative object Experiencer), whereas semantically reversible sentences with dative object Experiencers did, even in the canonical order. Thus, an account postulating that object Experiencers are more difficult to process than subject Experiencers because they are more complex does not explain our data, specifically the findings from the semantically irreversible sentences, and neither does an account that postulates a facilitating role of canonical thematic hierarchy, as shown by the patients' overall poor comprehension of dative object Experiencers in semantically reversible sentences. However, AD patients' poor comprehension of object Experiencers in semantically reversible sentences is aligned with the findings on cognitively more demanding processing of object Experiencers in cognitively normal population (Brennan and Pylkkänen, 2010), causing comprehension and production difficulties in speakers with language disorders due to brain damage (Piñango 2000; Thompson and Lee 2009).

What is interesting about our data is that they suggest a more complex picture of verb deficits in $A D$ than previously assumed. First, even at the stages of mild and moderate dementia Spanish AD patients retain the ability to comprehend both subject and object Experiencers in semantically irreversible sentences (as long as they are plausible). This pattern clearly does not match the comprehension pattern for irreversible sentences with psych verbs found in English AD patients (Manouilidou et al. 2009). Second, Spanish AD patients also retain the ability to comprehend sentences with agentive verbs, and this was also found in English-speaking $\mathrm{AD}$ patients. Third, Spanish AD patients had difficulty comprehending object Experiencers in semantically reversible sentences (which were not tested in the above discussed English study). Thus, our data indicate that, unlike sentences with agentive verbs, sentences with psych verbs that contain two animate NPs pose a problem to Spanish AD patients. Excluding Agent and agentive contexts, the difficulty in assigning correct thematic roles is present in sentences with two animate NPs, i.e. the roles that are further down the thematic hierarchy cannot be correctly assigned, regardless of whether the sentence is in the marked (<Theme, Experiencer $>$ ) or unmarked word order (<Experiencer, Theme $\rangle$ ). This indicates that the patients do not benefit from the morphosyntactic cues, such as particle $a$ indicating animate objects, case marking and the clitic doubling the object, which normally make the role of the object Experiencer predictable.

One could argue that the reversible sentences in Experiment 2 were simply more difficult to comprehend since they are longer than the irreversible sentences with dative object Experiencers in Experiment 1, and in addition the task in Experiment 2 was to answer a comprehension question. Thus, to achieve a score on such 
a sentence, the patients had to not only comprehend two sentences (the target and the question), but also to compare their meanings before deciding on how to answer the question. While this objection is justified, it does not explain our data, because the same sentence frame was used for sentences with agentive verbs, which AD patients comprehended above chance. Thus, something else, not the task complexity, detrimentally affected patients' comprehension of reversible sentences with dative object Experiencers.

Looking at the Spanish data from healthy young individuals (Gattei et al. 2015), we notice some similarities in their response patterns and our AD data. First, in both datasets there was more accuracy in the comprehension of dative object Experiencers when sentences were in OVS order (88.72\% healthy young, 59\% $\mathrm{AD}$ patients) than in SVO order (60.78\% in healthy young, $51 \%)$. Second, the opposite pattern was found in the comprehension of sentences with activity verbs, i.e. higher accuracy in sentences in SVO order ( $84.8 \%$ healthy young, $73.75 \% \mathrm{AD}$ patients) than in OVS order (69.36\% healthy young, $68.75 \%$ AD patients). Thus, despite the lack of statistically significant differences between the sentences in two word orders for both verb types in our data, $\mathrm{AD}$ patients' comprehension pattern indicating OVS > SVO for psych verbs and SVO > OVS for action verbs resembles the pattern found in healthy young speakers.

We are cautious in drawing too strong conclusions from the observed disparities between the English (Manouilidou et al. 2009) and Spanish AD data, on the one hand, and similarities between the Spanish AD data and Spanish data from young healthy individuals (Gattei et al. 2015), on the other, because these studies used different tasks (completion of written sentences, acceptability judgments of spoken language, reading comprehension), possibly tapping into additional, uncontrolled processes. Yet, it is plausible that the discrepancy in English and Spanish AD findings is due to differences in word orders in these languages (strict, flexible) and differential cues to thematic roles' assignment.

Assuming that sentence parsing unfolds in an incremental manner (Bornkessel et al. 2003, 2005), one would predict spared comprehension of object-initial sentences with dative Experiencers in $\mathrm{AD}$ in reversible sentences, owing to the available morphosyntactic information (particle $a$, case marking, clitic doubling), which appear pre-verbally. These cues are expected to facilitate integration of structural information in predictive sentence processing, as appears to be the case with comprehension of irreversible sentences with dative object Experiencers in Spanish $A D$ patients. This is also the case with semantically reversible sentences with the Agent role. But when the role of Agent is missing in semantically reversible sentences, as is the case with sentences with psych verbs, animacy and other cues that support predictive sentence processing do not facilitate $\mathrm{AD}$ patients' assignment of thematic roles further down the thematic hierarchy, regardless of word order, and patients cannot decide "who felt what for whom". While this finding is compatible with the general notion that 
$\mathrm{AD}$ patients have impaired thematic role assignment in sentences involving psych verbs (Manouilidou et al. 2009), at least in semantically reversible sentences in the case of Spanish, it also emphasizes the relevance of animacy. In Spanish, animacybased heuristics is an efficient comprehension strategy for semantically irreversible sentences with psych verbs as well as semantically reversible sentences with agentive verbs, but not for sentences with psych verbs that contain two animate NPs.

The present study has certain limitations. First, although small samples are typical for studies investigating language disturbances, which is mostly due to difficulties in recruiting a homogenous group of patients, it is nevertheless a limitation, and thus the findings of the present study need to be considered with this caveat in mind. For instance, the difference in recall of psych verbs and action verbs, which did not survive a Bonferroni correction for multiple comparisons, is a plausible effect in the context of present design, because of the patients' larger exposure to psych verbs during the testing session. Specifically, out of 40 psych verbs tested across two experiments, 30 were tested twice (in plausible and implausible sentences), which increases the chance of recalling such verbs immediately postexperiment. Similarly, although significant, the differences between patients' comprehension of plausible and implausible sentences did not survive correction, except for dative object Experiencers, which indicates that even though separated by the chance threshold, these differences were trivial, i.e. the scores were insufficiently distant from the threshold. Studies with larger samples will be able to determine whether there are effects in these cases.

However, research on verb deficits in Spanish $\mathrm{AD}$ patients is scarce, despite the large presence of this language across the world. At the same time, $\mathrm{AD}$ is the most common type of dementia, which currently accounts for $60-80 \%$ of dementia, affecting 35 million people worldwide (Riedel 2014). In view of these facts, we believe that the present findings and the value of sharing new data from Spanish on this intriguing linguistic topic balance out the "cost" of running a study with a smaller than optimal sample size, while keeping in mind that it is important to replicate the present findings with a larger sample and ensure that important effects were not left unobserved due to reduced power. Another possible limitation is lack of neuroimaging data, which precluded insights into the relationship between neuropathology in mild vs. moderate $\mathrm{AD}$ and the comprehension patterns observed in our sample. Future research should also determine possible neural markers preceding verb deficits, therefore looking at the neural correlates of processing of psych verbs in predementia stages.

Before we conclude this section, one observation on MoCA is in order. The lack of significant correlations between $\mathrm{AD}$ patients' MoCA scores and their comprehension scores, on the one hand, and recall scores, on the other, is worth attention, given that $\mathrm{MoCA}$ is an assessment of cognition, which is impaired in $\mathrm{AD}$. The finding that MoCA is not sensitive enough to register verb deficits in $\mathrm{AD}$ is not surpris- 
ing, if one looks more closely at its subtests. For instance, (a) MoCA tests memory for words in delayed recall of a list of five nouns and no verbs, (b) its naming subtest requires retrieval of names for objects and no actions, and (c) the subtest testing specifically for language requires sentence repetition only. This indicates a need for cognitive tests that would reliably point to deterioration of language in $\mathrm{AD}$ across various levels of structure. So far, research on verb deficits in AD (e.g. Robinson et al. 1996; White-Devine et al. 1996; Grossman et al. 2007; Monouilidou et al. 2010) has not been taken into account by the experts working on introducing more sensitive tests of cognitive deficits in AD. Such tests are much needed. To illustrate the point, the European Prevention of AD Program, which was launched in 2015, has recommended certain changes to the assessment of cognitive outcomes in preclinical AD3 (Ritchie et al. 2017), suggesting that multiple cognitive domains, including language, are likely to be affected along the trajectory from preclinical AD to MCI. However, the revised tests for language are still coarse, including for instance picture naming and semantic fluency, which in fact assess only memory for language.

In conclusion, regardless of its preliminary nature and the small sample size, our study offers a novel insight into AD patients' ability to comprehend sentences with psych verbs and recall incidentally coded psych verbs, generating novel, testable hypotheses on the nature of verb deficits in AD.

\section{Acknowledgment}

We thank Lucas J.M. Almagro, Universidad de Málaga, for collecting data from cognitively healthy participants.

\section{References}

Belletti, Adriana and Luigi Rizzi (1988). Psych verbs and $\theta$-theory. Natural Language and Linguistic Theory 3: 291-352

Bornkessel, Ina, Matthias Schlesewsky andAngela D. Friederici(2003). Eliciting thematicreanalysis effects: The role of syntax-independent information during parsing. Language and Cognitive Processes 18: 269-298, https://doi.org/10.1080/01690960244000018

Bornkessel, Ina, Stefan Zysset, Angela D. Friederici, Yves D von Cramon and Matthias Schlesewsky (2005). Who did what to whom? The neural basis of argument hierarchies during language comprehension. NeuroImage 26: 221-233, https://doi.org/10.1016/j.neuroimage.2005.01.032

3 Recently revised research and diagnostic criteria for $\mathrm{AD}$ suggest that $\mathrm{AD}$ is a continuum, including the preclinical stage, where brain pathology is present, but cognitive changes are still absent or very subtle, then the prodromal stage (i.e. mild cognitive impairment, MCI) and AD dementia (Dubois et al. 2007, 2010, 2014; Sperling et al. 2011). 
Brennan, Jonathan and Liina Pylkkänen (2010). Processing psych verbs: Behavioural and MEG measures of two different types of semantic complexity. Language and Cognitive Processes 25: 777-807, https://doi.org/10.1080/01690961003616840

De Bruyne, Jacques (1995). A comprehensive Spanish grammar. Wiley

Dere, Ekrem, Bettina M. Pause and Reinhard Pietrowsky (2010). Emotion and episodic memory in neuropsychiatric disorders. Behavioral Brain Research 215: 162-171, https://doi.org/10.1016/j.bbr.2010.03.017

Dickerson, Bradford C., Akram Bakkour, David H. Salat, Eric Feczko, Jenni Pacheco et al. (2009). The Cortical Signature of Alzheimer's disease. Cerebral Cortex 19: 497-510, https://doi.org/10.1093/cercor/bhn113

Dubois, Bruno, Howard H. Feldman, Claudia Jacova, Steven T. Dekosky, Pascale Barberger-Gateau, Jeffrey Cummings et al. (2007). Research criteria for the diagnosis of Alzheimer's disease: revising the NINCDS-ADRDA criteria. Lancet Neurology 6(8): 734-746, https://doi.org/10.1016/s1474-4422(07)70178-3

Dubois, Bruno, Howard H. Feldmann, Claudia Jacova, Jeffrey L. Cummings, Steven T. Dekosky, Pascale Barberger-Gateau et al. (2010). Revising the definition of Alzheimer's disease: a new lexicon. Lancet Neurology 9: 1118-1127, https://doi.org/10.1016/s1474-4422(10)70223-4

Dubois, Bruno, Howard H. Feldmann, Claudia Jacova, Harald Hampel, José Luis Molinuevo, Kaj Blennow et al. (2014). Advancing research diagnostic criteria for Alzheimer's disease: the IGW-2 criteria. Lancet Neurology 13: 614-629, https://doi.org/10.1016/s1474-4422(14)70090-0

Ekman, Paul (1999). Basic emotions. Dalgleish, Tim and Mick Power, eds. Handbook of cognition and emotion. John Wiley \& Sons Ltd.

Fábregas, Antonio and Rafael Marín (2015). Deriving individual-level and stage-level psych verbs in Spanish. The Linguistic Review 32(2): 167 - 215,

https://doi.org/10.1515/tlr-2014-0022

Fernández Soriano, Olga (1999). Two types of impersonal sentences in Spanish: Locative and dative subjects. Syntax 2(2): 101-140, https://doi.org/10.1111/1467-9612.00017

Franco, Jon (1990). Towards a Typology of Psych Verbs: Evidence from Spanish. Green, Thomas and Sigal Uziel, eds. Proceedings of 2nd Meeting of SCIL, MITWPL 12, 46-62

Folstein, Marshall F., Susan E. Folstein and Paul R. McHugh (1975). "Mini-mental state": a practical method for grading the cognitive state of patients for the clinician. Journal of Psychiatric Research 12: 189-198, https://doi.org/10.1016/0022-3956(75)90026-6

Gattei, Carolina, Michael W. Dickey, Alejandro J. Wainselboim and Luis París (2015). The thematic hierarchy in sentence comprehension: a study on the interaction between verb class and word order in Spanish. Quarterly Journal of Experimental Psychology 68: 1981-2007, https://doi.org/10.1080/17470218.2014.1000345

Giffard, Bénédicte et al. (2015). An exploration of semantic network in Alzheimer's disease: Influence of emotion and concreteness of concepts. Cortex 69: 201-211, https://doi.org/10.1016/j.cortex.2015.05.020 
Grossman, Murray, Ryan Murray, Phyllis Koenig, Sherry Ash, Katy Cross, Peachie Moore and Vanessa Troiani (2007). Verb acquisition and representation in Alzheimer's disease. Neuropsychologia 45(11): 2508-2518, https://doi.org/10.1016/j.neuropsychologia.2007.03.020

Hartshorne, Joshua K., Timothy J. O’Donnell, Yasutada Sudo, Miki Uruwashi, Miseon Lee and Jesse Snedeker (2016). Psych verbs, the linking problem, and the acquisition of language. Cognition 157: 268-288, https://doi.org/10.1016/j.cognition.2016.08.008

Jiménez-Fernández, Ángel Luis and Bozena Rozwadowska (2016). The information structure of Dative Experiencer psych verbs. Cetnarowska, Bozena, Marcin Kuczok and Marcin Zabawa, eds. Various dimensions of contrastive studies. Katowice: Wydawnictwo Uniwersytetu Śląskiego

Kail, Michèle and Agnès Charvillat (1988). Local and topological processing in sentence comprehension by French and Spanish children. Journal of Child Language 15: 637662, https://doi.org/10.1017/s0305000900012605

Kim, Mikyong and Cynthia K. Thompson (2004). Verb deficits in Alzheimer's disease and agrammatism: implications for lexical organization. Brain \& Language 88(1): 1-20, https://doi.org/10.1016/s0093-934x(03)00147-0

Kljajevic, Vanja, Michel Jan Grothe, Michael Ewers and Stefan Teipel (2014). Distinct pattern of hypometabolism and atrophy in preclinical and predementia Alzheimer's disease. Neurobiology of Aging 35: 1973-1981, https://doi.org/10.1016/j.neurobiolaging.2014.04.006

Kljajevic, Vanja, Estibaliz Ugarte Gómez, Cristina López and Yolanda Balboa Bandeira (2019). In search for common patterns in aphasia: the case of Spanish wh-dependencies. Journal of Communication Disorders 82: 105924, https://doi.org/10.1016/j.jcomdis.2019.105924

Landau, Idan (2010). The locative syntax of Experiencers. Cambridge, MA: The MIT Press. Christina Manouilidou, Roberto G. de Almeida, George Schwartz and N.P.V. Nair (2009). Thematic roles in Alzheimer's disease: hierarchy violations in psychological predicates. Journal of Neurolinguistics 22(2): 167-186, https://doi.org/10.1016/j.jneuroling.2008.10.002

Massulo, P.J. (1992). Quirky datives in Spanish and the non-nominative subject parameter. Kathol, A. and J. Beckman, eds. Proceedings of the 4th Meetings of SCIL, 89-103. MITWPL 16

McKhann, Guy, David Drachman, Marshall Folstein, Robert Katzman, Donald Price and Emanuel M. Stadlan (1984). Clinical diagnosis of Alzheimer's disease: report of the NINCDS-ADRDAWork Group under the auspices of Department of Health and Human Services Task Force on Alzheimer's Disease. Neurology 34: 939-944, https://doi.org/10.1212/wnl.34.7.939

Nasreddine, Ziad S., Natalie A. Phillips, Valérie Bédirian, Simon Charbonneau, Victor Whitehead, Isabelle Collin et al. (2005). The Montreal Cognitive Assessment, MoCA: A Brief Screening Tool for Mild Cognitive Impairment. Journal of the American Geriatrics Society 53: 695-699, https://doi.org/10.1111/j.1532-5415.2005.53221.x 
Ostrosky-Solis, Feggy, Jose Marcos-Ortega, Alfredo Ardila, Monica Rosselliand Silvia Palacios (1999). Syntactic comprehension in Broca's Spanish-speaking aphasics: Null effect of Word order. Aphasiology 13: 553-571, https://doi.org/10.1080/026870399402000

Pesetsky, David (1995). Zero syntax. Experiencers and cascades. Cambridge, MA: The MIT Press Piñango, Maria Mercedes (2000). Canonicity in Broca's sentence comprehension: The case of psychological verbs. Grodzinsky, Yosef, Lewis P. Shapiro and David Swinney, eds. Language and the Brain: Representing and Processing. Academic Press, San Diego, 327-350

Ritchie, Karen, Michael Ropacki, Bruce Albala, John Harrison, Jeffrey Kaye, Joel Kramer et al. (2017). Recommended cognitive outcomes in preclinical Alzheimer's disease: Consensus statement from the European Prevention of Alzheimer's Dementia project. Alzheimer's \& Dementia 13(2): 186-195, https://doi.org/10.1016/j.jalz.2016.07.154

Riedel,WimJ.(2014). Preventingcognitivedeclinein preclinicalAlzheimer's disease.Current Opinion in Pharmacology 14: 18-22, https://doi.org/10.1016/j.coph.2013.10.002

Robinson, Keith M., Murray Grossman, Tammy White-Devine and Mark D’Esposito (1996). Category-specific difficulty naming with verbs in Alzheimer's disease. Neurology 47(1):178-182, https://doi.org/10.1212/wnl.47.1.178

Sperling, Reisa A., Paul S Aisen, Laurel A. Beckett, David A. Bennett, Suzanne Craft et al. (2011). Toward defining the preclinical stages of Alzheimer's disease: Recommendations from the National Institute on Aging-Alzheimer's Association workgroups on diagnostic guidelines for Alzheimer's disease. Alzheimer's \& Dementia 7: 280-292, https://doi.org/10.1016/j.jalz.2011.03.003

Sturm, Virginia E., Jennifer S. Yokoyama, William W. Seeley, Joel H. Kramer, Bruce L. Miller and Katherine P. Rankin (2013). Heightened emotional contagion in mild cognitive impairment and Alzheimer's disease is associated with temporal lobe degeneration. PNAS 1109944-1109949, https://doi.org/10.1073/pnas.1301119110

Taler, Vanessa, Shari R. Baum, Howard Chertkow and Daniel Saumier (2008). Comprehension of grammatical and emotional prosody is impaired in Alzheimer's disease. Neuropsychology 22: 188-195, https://doi.org/10.1037/0894-4105.22.2.188

Thompson, Cynthia K. and Miseon Lee (2009). Psych verbs production and comprehension in agrammatic Broca's aphasia. Journal of Neurolinguistics 22: 354-369, https://doi.org/10.1016/j.jneuroling.2008.11.003

White-Devine, Tammy, Murray Grossman, Keith M. Robinson, Kris Onishi and Nadia Biassou (1996). Verb confrontation naming and word-picture matching in Alzheimer's disease.Neuropsychology10(4):495-503,https://doi.org/10.1037/0894-4105.10.4.495

Wierzbicka, Anna (1981). Case marking and human nature. Australian Journal of Linguistics 1: 43-80, https://doi.org/10.1080/07268608108599266 


\section{Razumijevanje psiholoških predikata kod Alzheimerove demencije}

Pacijenti s dijagnozom Alzheimerove bolesti imaju deficit u razumijevanju rečenica s psihološkim predikatima. Podaci iz engleskog pokazuju da je deficit u njihovu razumijevanju rečenica $s$ objektom doživljavačem izraženiji u odnosu na deficit u njihovu razumijevanju rečenica sa subjektom doživljavačem. Budući da se španjolski po strukturi razlikuje od engleskog, u ovoj studiji istraživali smo pokazujuli španjolski govornici s dijagnozom Alzheimerove bolesti drugačiji obrazac u razumijevanju psiholoških predikata.

Testirali smo razumijevanje semantički ireverzibilnih rečenica sa subjektom doživljavačem i objektom doživljavačem u dativu i akuzativu kod deset izvornih govornika španjolskog s dijagnozom blage do umjerene Alzheimerove demencije. Također smo testirali njihovo razumijevanje semantički reverzibilnih rečenica s objektom doživljavačem u dativu u SVO i OVS redu riječi.

Rezultati statističkih analiza pokazuju da je kod španjolskih govornika s dijagnozom Alzheimerove demencije razumijevanje psiholoških glagola očuvano u semantički ireverzibilnim rečenicima bez statistički značajnih razlika u razumijevanju subjekt- vs. objekt-doživljavača ili između objektnih doživljavača u akuzativu i dativu. Međutim, njihovo razumijevanje dativnih doživljavača u semantički reverzibilnim rečenicama je deficitno, bez obzira na red riječi, što nije slučaj s glagolima akcije čije je razumijevanje očuvano.

Dakle, ovi podaci sugeriraju da se deficit razumijevanja psiholoških glagola kod govornika španjolskog $s$ dijagnozom blage do umjerene Alzheimerove demencije manifestira drugačije u odnosu na engleski, te da je deficit u razumijevanju psiholoških predikata kod Alzheimerove demencije heterogeniji nego što se smatralo do sada.

Keywords: psych verbs, sentence processing, Alzheimer's disease, Spanish language

Ključne riječi: psihološki glagoli, razumijevanje rečenice, Alzheimerova demencija, španjolski jezik 